\title{
COVID-19: Need for technological independence
}

\section{COVID-19: Necesidad de independencia tecnológica}

\author{
Martha Lucía Ospina Ramírez \\ mospina@ins.gov.co \\ Director of Instituto Nacional de Salud. Bogotá D.C. Colombia, Bogotá, Colombia
}

\section{G open Access}

Citation: Ospina RML. Colomb Med (Cali). 2020; 51(2):e4334. http://doi.org/10.25100/ cm.v51i2.4334

Received : 02 Apr 2020

Revised : 25 Apr 2020

Accepted : 04 May 2020

Published: 11 May 2020

Keywords:

Coronavirus, covid-19, pandemics, vaccination Coverage, Uncertainty, Indicators and Reagents, Economic Recession

\section{Palabras clave:}

Coronavirus,covid-19, pandemia, cobertura de vacunación, incertidumbre, indicadores y reactivos, recesión económica.

Copyright: (c) 2019. Universidad del

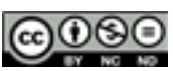

Among so many verbs that have become fashionable in these times of pandemic -infect, spread, analyse, isolate, care-, there is one that, at first glance, seems foreign to the occasion: strip.

This verb is figuratively repeated in hundreds of speeches - "the covid-19 stripped ..., "the coronavirus stripped ..." "the pandemic stripped ..." -, reminding us that a good part of these material and social progress we were so proud of, leaned on feet of clay.

Reality is stubborn. The coronavirus, in effect, not only infected our organisms, but it also severely exposed our technological dependence.

It is undeniable that globalization brought countless benefits. It allowed us to have goods and services from anywhere in the world and expand our frontiers of knowledge. But we never anticipated that the global village we were building would be re-parcelled and closed.

The Colombian National Institute of Health was a great producer of vaccines throughout the 20th century. Millions of doses of vaccines against yellow fever, rabies, diphtheria and tetanus were produced annually in their laboratories. Smallpox eradication in 1979 was achieved with products that had been produced locally since 1897 . The country even exported organic products to more than 20 countries in Central America, South America, the Caribbean and Africa.

Those capabilities were eclipsed at the end of the last century. The economic crisis resulted in the obsolescence of laboratories, and that obsolescence, in the loss of certificates of good manufacturing practices. Local technology did not update itself and we became importers of vaccines.

At the time we were not sorry. The doors were open to bring very good quality products. And the truth is that we still have satisfactory vaccination coverage. But, do we have the same tranquillity as before? Will we always have those vaccines? We do not know: the pandemic exposed our uncertainty.

Counterfactual stories are unfriendly. But, undoubtedly, if our policies had continued to stimulate research and manufacturing of pharmaceutical products, today we would have the capacity - or we would not be so far from having it - to produce the reagents that are so scarce in the international market today and that we need so much for the covid-19 diagnosis. We would not be wondering what place in line we are going to have to receive the vaccine or the treatment that will finally get us out of this crisis. 
Valle.

Conflict of Interest:

None

Corresponding author:

Martha Lucía Ospina Ramírez Instituto Nacional de Salud. Bogotá D.C. Colombia, Bogotá, Colombia e-mail: mospina@ins.gov.co
We would not be listening to speeches that insinuate that it is only a matter of "will to produce today". To say that with our current capabilities we can produce pharmaceutical or laboratory technology at an industrial level is the same as saying that you can have a cell phone operating company using the old Telecom facilities and equipment ${ }^{1}$.

The lesson learned is overwhelming. We can never again assume that there will always be a global market ready to sell us. We are urged to put an end to the supposedly realistic language, but defeatist in practice, according to which we will never have the infrastructure to produce high-tech medical supplies. We must begin to believe that Colombia can be the cradle of scientists and large pharmaceutical ventures.

It is no longer a choice. It has already been revealed that it is a matter of life and death. 